\title{
Potensi Selokan Mataram: ulasan keadaan fisik dan kualitas airnya
}

\author{
Pipin Kusumawati*, Achmad Andi Rif'an**, dan Eko Sugiarto** \\ * Program Studi D3 Perhotelan Sekolah Tinggi Pariwisata Ambarrukmo \\ Yogyakarta \\ ** Program Studi S1 Hospitality Sekolah Tinggi Pariwisata Ambarrukmo \\ Yogyakarta
}

\begin{tabular}{l}
\hline \hline INFO ARTIKEL \\
\hline Riwayat Artikel: \\
Dikirim: 22-11-2018 \\
Disetujui: 22-5-2019 \\
Diterbitkan: 30-6-2019 \\
\hline
\end{tabular}

Kata kunci:

Selokan Mataram; Kondisi

Fisik; Kualitas Air
Alamat Korespondensi:

Pipin Kusumawati

\begin{abstract}
ABSTRAK
Abstract: The Mataram Canal is a historical inscription of the policy of Mataram's King which had saved thousands of Yogyakarta residents from the obligation to become Romusha during the Japanese colonialism. The inscription still stands today and has widely used for agricultural irrigation. Although it has a long interesting history and supported by beautiful natural scenery, this place has not been managed for tourism purposes. For this reason, this research is an initial study that will review the physical condition of Mataram Canal and the quality of the water. The Mataram Canal landscape is quite beautiful but requires a lot of repairs in several parts. Water quality also showed that the water does not meet favorable standards caused by sampling carried out in the rainy season. Thus the need for research in the dry season which could be used as a reference in determining the feasibility of Mataram Canal as a water tourism attraction.
\end{abstract}

Abstrak: Selokan Mataram adalah prasasti sejarah kebijakan Raja Mataram yang telah menyelamatkan ribuan penduduk Yogyakarta dari kewajiban menjadi Romusha pada masa penjajahan Jepang. Prasasti tersebut masih berdiri hingga saat ini dan dimanfaatkan secara luas untuk pengairan pertanian. Meskipun memiliki sejarah yang panjang dan menarik serta didukung dengan potensi alam yang cukup indah, tempat ini kurang dimaksimalkan untuk tujuan wisata. Untuk itu penelitian ini adalah penelitian awal yang akan mengulas keadaan fisik Selokan Mataram dan kualitas airnya. Lanskap Selokan Mataram dinilai cukup indah tetapi membutuhkan banyak perbaikan di beberapa bagian. Kualitas air juga menunjukkan kualitas air yang tidak memenuhi standar yang kemungkinan disebabkan oleh pengambilan sampel yang dilakukan pada musim penghujan. Dengan demikian perlu adanya penelitian lanjutan yang membandingkan kualitas air Selokan Mataram pada musim kemarau sehingga dapat dijadikan acuan dalam penentuan kelayakan Selokan Mataram sebagai wahana wisata tirta.

This is an open access article under the CC-BY-SA license.

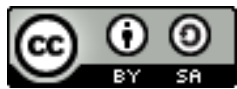


Jurnal Pendidikan Geografi:

Kajian, Teori, dan Praktik dalam Bidang Pendidikan dan Ilmu Geografi

Tahun 24, Nomor 2, Jun 2019, Hal 108-118

Program Studi D3 Perhotelan

Sekolah Tinggi Pariwisata Ambarrukmo (STIPRAM) Yogyakarta

Jl Ahmad Yani 52 Ringroad Timur, Yogyakarta 55198 Indonesia

E-mail: pipinkusumawati@gmail.com

\section{PENDAHULUAN}

Indonesia adalah negera kepulauan yang memiliki bentang alam beragam yang dapat berperan sebagai daya tarik wisata. Kelestarian sumber daya alam akan tetap terjaga apabila sumber daya alam tersebut dikelola sesuai dengan keunikan dan kapasitasnya masing-masing (Wirakusuma, 2017). Dalam Undang-Undang Presiden Republik Indonesia (2009) Nomor 10 tentang Kepariwisataan disebutkan bahwa wisata merupakan sebuah kegiatan perjalanan yang dilakukan untuk sementara waktu dengan maksud untuk mendapatkan kesenangan, pengembangan pribadi, atau mempelajari keunikan tempat dengan cara mengunjungi suatu daya tarik wisata baik yang dilakukan oleh seseorang maupun sekelompok orang.

Daya tarik wisata merupakan sesuatu yang dapat menarik seseorang menuju ke suatu destinasi dan merupakan alasan utama bagi seseorang yang melakukan kegiatan pariwisata. Ada tiga syarat yang harus dipenuhi agar suatu tempat bisa menjadi daya tarik wisata, yaitu: ada sesuatu yang bisa dilihat, sesuatu yang bisa dikerjakan, dan sesuatu yang bisa dibeli (Soekadijo, 2000; Karyono, 1997; Rif'an, 2016).

Menurut Syahrul (2006) dalam Romaito et al. (2014), wisata dibidang perairan dapat dibedakan menjadi dua, yaitu wisata tirta (perairan tawar) dan wisata bahari (perairan laut). Wisata tirta adalah wisata yang dilakukan di perairan tawar dengan aktivitas yang dilakukan seperti olahraga, sight seeing, memancing, dan lain-lain yang dilakukan di sungai, waduk, danau, dan kawasan-kawasan rawa-rawa serta muara. Selain indah, sungai selalu terkait dengan peradaban manusia. Perairan menyediakan air dan tanah aluvial yang subur untuk sumber pangan, pertanian dan perdagangan (Ernawati, et al., 2018).

Wisata air dapat dibagi menjadi berbagai kegiatan, sehingga kualitas air pun disesuaikan dengan kegiatan wisata air yang dilakukan (South Africa's Department of Water Affairs and Forestry, 1996). Terdapat 3 kategori besar penggunaan air dengan tujuan wisata, yaitu:

\section{Wisata air kontak penuh}

Wisata air ini melibatkan kontak penuh tubuh terhadap air, mencakup aktivitas seperti berenang dan menyelam. Wisatawan dewasa seringkali mengajak anak-anaknya ikut dalam wisata ini, yang membuat wisata jenis ini lebih rentan terhadap sejumlah penyakit menular dan status kesehatan wisatawan membuat wisata ini lebih rentan terhadap berbagai efek penyakit menular melalui air (waterborne diseases). Kualitas air khusus kolam renang dan pemandian umum mengacu pada Permenkes no.32 tahun 2017 Tentang Standar Baku Mutu Kesehatan Lingkungan Dan Persyaratan Kesehatan Air Untuk Keperluan Higiene Sanitasi, Kolam Renang, Solus Per Aqua, Dan Pemandian Umum.

\section{Wisata air kontak menengah}

Wisata ini mencakup kegiatan yang melibatkan kontak air cukup tinggi, seperti ski air, berperahu, kano dan memancing hingga kontak air yang relatif sedikit, seperti mendayung. Faktor utama yang membedakan kategori wisata air menengah dengan wisata air kontak penuh adalah tingkat kontak terhadap air hanya akan terjadi sesekali. Usia wisatawan yang datang biasanya remaja hingga dewasa dan dengan status kesehatan yang cukup baik. 
Jurnal Pendidikan Geografi:

Kajian, Teori, dan Praktik dalam Bidang Pendidikan dan Ilmu Geografi

Tahun 24, Nomor 2, Jun 2019, Hal 108-118

\section{Wisata Air non kontak}

Wisata air non-kontak meliputi segala bentuk rekreasi yang tidak melibatkan kontak langsung dengan air. Kegiatannya seperti piknik dan hiking di tepi badan air atau menikmati pemandangan air oleh wisatawan yang berlibur di tepi badan air. Nilai ekonomi wisata air terkait erat dengan estetika pemandangan badan air karena ini merupakan faktor utama dalam menentukan nilai wisatanya. Karena tidak ada kontak air, efek kesehatan masyarakat yang terkait dengan kontak air hampir minimal.

Indonesia memiliki kekayaan alam dengan segala sumber daya alamnya yang melimpah. Di antara sumber daya alam tersebut, banyak yang bisa dimanfaatkan sebagai daya tarik wisata. Salah satu sumber daya alam yang potensial untuk dikembangkan dan dapat menarik minat wisatawan adalah wisata yang terkait dengan air. Menurut Gutt dan Var (2002) sumber daya air seperti pantulan kolam, air mancur, sungai, danau, air terjun, dan laut menyajikan daya tarik yang tidak tergantikan. Wisata dengan memanfaatkan sumber daya air yang juga disebut dengan usaha wisata tirta berdasakan Undang-Undang Presiden Republik Indonesia (2009) Nomor 10 tentang Kepariwisataan merupakan usaha yang menyelenggarakan wisata dan olahraga air, termasuk penyediaan sarana dan prasarana serta jasa lainnya yang dikelola secara komersial di perairan laut, pantai, sungai, danau, dan waduk. Konsep manajemen wisata alam, salah satunya wisata tirta tidak boleh hanya fokus pada jumlah pengunjung demi keuntungan ekonomi tetapi juga kelestarian lingkungan sehingga memberi manfaat kepada masyarakat sekitarnya karena dampak negatif wisata alam justru dapat menyebabkan degradasi ekosistem (NPWS 2001 dalam Rahmafitria, et al., 2017).

Selokan Mataram merupakan salah satu landmark Kota Yogyakarta (Hadiyanti \& Wibisono, 2012). Selokan ini sebenarnya bukan sungai alami, melainkan sungai buatan yang memiliki nilai sejarah yang tinggi. Selokan Mataram dibangun pada masa Jepang merupakan prakarsa Raja Keraton Ngayogyakarto Hadiningrat, Sri Sultan Hamengku Buwono IX. Sultan HB IX pada masa kependudukan Jepang di Indonesia bermaksud membuat Selokan Mataram agar rakyat Yogyakarta terhindar dari kerja paksa penjajah Jepang. Pada masa itu Jepang membutuhkan banyak tenaga kerja untuk membangun di berbagai daerah. Proyek tersebut terutama untuk memperkuat kedudukan mereka di Nusantara, terlebih dalam menghadapi pihak sekutu yang sewaktu-waktu menyerang. Agar rakyat Yogyakarta tidak dipekerjakan sebagai romusha di berbagai daerah, Sri Sultan HB IX berinisiatif membuat selokan tersebut. Usaha itu membuahkan hasil sehingga rakyat Yogyakarta terhindar dari kerja paksa (https://news.detik.com/berita-jawa-tengah/d-3641905/selokan-mataram-diyogya-sarat-nilai-sejarah-justru-dipenuhi-sampah). Selain sejarah, ada pula legenda mengenai Selokan Mataram yang dipercaya oleh masyarakat Yogyakarta pada masa itu. Legenda tersebut didasarkan dari pernyataan Sunan Kalijaga bahwa Yogyakarta akan makmur apabila Sungai Progo dan Sungai Opak bersatu. Bersatunya Sungai Progo dan Sungai Opak pada akhirnya dapat terjadi dengan adanya teknologi pembangunan berupa Selokan Mataram. Dipercaya atau tidak, pembangunan Selokan Mataram memberi banyak kontribusi terhadap kehidupan masyarakat Yogyakarta hingga saat ini (Senui dalam Adiarti, 2011).

Sesuai tujuannya, hingga saat ini pemanfaatan Selokan Mataram terbatas pada saluran irigasi bagi persawahan yang dilalui Selokan Mataram. Selokan yang berhulu di Sungai Progo di Bendungan Karang Talun, Dusun Ancol, Desa Bligo, Kecamatan Ngluwar, Kabupaten Magelang ini kemudian membagi dua alirannya, yaitu saluran Van Der Wijck untuk mengairi persawahan dan perkebunan di daerah Moyudan terus ke Selatan serta saluran Selokan Mataram yang berlanjut masuk ke wilayah kota Yogyakarta sampai bermuara di Sungai Opak, Kabupaten Klaten. 
Jurnal Pendidikan Geografi:

Kajian, Teori, dan Praktik dalam Bidang Pendidikan dan Ilmu Geografi

Tahun 24, Nomor 2, Jun 2019, Hal 108-118

Bendungan Karang Talun yang terletak di Dusun Ancol merupakan hulu dari selokan yang cukup sering didatangi wisatawan terutama pada hari libur. Selain menyaksikan konstruksi irigasi bersejarah, di kawasan ini pengunjung juga bisa menikmati keindahan lanskap Sungai Progo dengan latar belakang Perbukitan Menoreh yang hijau. Keberadaan pepohonan yang cukup rindang di area Ancol membuat pengunjung betah berlama-lama di sana. Meskipun memiliki sejarah yang panjang dan menarik serta didukung potensi alam yang cukup indah, tempat ini kurang dimaksimalkan untuk tujuan wisata karena tidak ada fasilitas penunjang seperti kamar mandi/toilet (http://www.kotawates.com/ancol-jogja-sejarahselokan-matram-tempo-dulu.html).

Aktivitas wisata di bagian hulu Selokan Mataram perlu dikembangkan mengingat potensinya yang cukup besar menjadi sebuah daya tarik wisata tirta. Berdasar latar belakang tersebut, penelitian ini bertujuan untuk mengetahui kelayakan Selokan Mataram untuk aktivitas wisata tirta terutama dilihat dari aspek fisik, dan kualitas airnya. Kualitas air penting diperhatikan karena menurut Asrini et al. (2017), penurunan kualitas air dapat menurunkan daya guna, dan daya tampung dari sumber daya air yang pada akhirnya menurunkan kekayaan sumber daya alam. Suyasa et al. (2018) menambahkan bahwa timbulan bau, kotor dan rendahnya estetika lingkungan air dapat mengancam keberlangsungan kegiatan pariwisata.

\section{METODE}

Penelitian lapangan dilakukan pada bulan November 2017. Penelitian lapangan ini bertujuan mengambil titik koordinat lokasi masing-masing spot untuk data pemetaan sekaligus untuk pengambilan sampel uji kualitas air. Sampel air diambil dari empat stasiun yang berbeda seperti terlihat pada Tabel 1 .

Tabel 1. Lokasi Pengambilan Sampel Air

\begin{tabular}{|c|c|c|}
\hline $\begin{array}{l}\text { Titik Sampling } \\
\text { Air }\end{array}$ & Titik Koordinat & Lokasi \\
\hline A & $\begin{array}{l}7^{\circ} 40^{\prime} 26^{\prime \prime} \mathrm{S} \\
110^{\circ} 16^{\prime} 1 " \mathrm{~T}\end{array}$ & $\begin{array}{c}\text { Bendungan Karang Talun, Dusun Ancol, Desa Bligo, Kecamatan Ngluwar, } \\
\text { Kabupaten Magelang }\end{array}$ \\
\hline B & $\begin{array}{l}7^{\circ} 42^{\prime} 43 ” \mathrm{~S} \\
110^{\circ} 17^{\prime} 10^{\prime \prime} \mathrm{T}\end{array}$ & $\begin{array}{c}\text { Dusun Susukan, Desa Margokaton, Kecamatan Seyegan, Kabupaten } \\
\text { Sleman }\end{array}$ \\
\hline $\mathrm{C}$ & $\begin{array}{l}7{ }^{\circ} 45^{\prime} 15^{\prime} \mathrm{S} \\
110^{\circ} 21 ’ 2 " \mathrm{~T}\end{array}$ & Dusun Nambungan, Desa Tlogoadi, Kecamatan Mlati, Kabupaten Sleman \\
\hline $\mathrm{D}$ & $\begin{array}{c}\text { 7036'26.76" S } \\
110^{\circ} 13 ’ 28.00^{\prime \prime} \mathrm{T}\end{array}$ & Desa Mendut, Kecamatan Mungkid, Kabupaten Magelang \\
\hline
\end{tabular}

Sumber: Observasi Lapangan, 2017

\section{Peralatan}

Alat yang digunakan dalam penelitian ini diantaranya adalah smartphone iPhone 5C untuk mendokumentasikan foto-foto dan titik koordinat masing-masing stasiun penelitian menggunakan aplikasi "Compass", empat buah jerigen berkapasitas satu liter, empat buah tabung kaca steril berkapasitas 300 mililiter, dan termometer.

\section{Metode Pengumpulan Data}

Data dikumpulkan dengan metode observasi yakni mengumpulkan data yang dilakukan dengan cara mengamati dan mencatat secara sistematik gejala-gejala yang diselidiki (Utama \& Mahadewi, 2012). Data yang diamati adalah kondisi fisik lingkungan Selokan Mataram, keadaan lahan pertanian di sepanjang Selokan Mataram, keadaan penduduk yang bermukim di sepanjang Selokan Mataram, ketersediaan sarana dan prasarana, aksesibilitas, dan lain-lain. 
Jurnal Pendidikan Geografi:

Kajian, Teori, dan Praktik dalam Bidang Pendidikan dan Ilmu Geografi

Tahun 24, Nomor 2, Jun 2019, Hal 108-118

\section{HASIL DAN PEMBAHASAN}

Penelitian ini mengambil 4 stasiun penelitian dengan adanya berbagai pertimbangan. Stasiun penelitian pertama (lokasi A) adalah titik bendungan Karang Talun di Dusun Ancol Bligo Ngluwar Magelang. Aliran airnya harus melewati bawah sungai Krasak sehingga tidak dapat dilalui perahu dan lokasi A harus berakhir di situ. Stasiun penelitian kedua (Lokasi B) dimulai dari Perempatan Jalan Nyangkringan hingga Dusun Susukan Margokaton Seyegan Sleman. Stasiun penelitian ketiga (Lokasi C) dimulai dari Dusun Nambungan Tlogoadi Mlati Sleman hingga Kecamatan Sinduadi Mlati Sleman, sedangkan lokasi D digunakan sebagai kontrol berada di Sungai Progo yang melintas di bawah Jalan Sudirman Borobudur Magelang Jawa Tengah yang menjadi cikal bakal aliran Selokan Mataram sekaligus lokasi wisata tirta arung jeram (rafting) sungai Progo. Pertimbangan adanya tiga lokasi penelitian untuk wisata tirta adalah dikarenakan adanya beberapa titik yang tidak memungkinkan dibukanya suatu wisata tirta, misalkan keterbatasan aksesibilitas ke daerah tersebut, kerusakan badan selokan mataram ataupun adanya talang sempit yang harus dilalui oleh badan air Selokan Mataram yang tidak dimungkinkannya dilewati suatu perahu/tube. Lokasi spot wisata juga dipilih jauh dari pemukiman padat penduduk/aktivitas manusia sehingga harapannya sampah/limbah yang dibuang ke badan air juga minimal.

Titik koordinat keempat stasiun penelitian dapat dilihat pada Tabel 2 yang selanjutnya diplotkan pada suatu peta yang dapat dilihat pada Gambar 1.

Tabel 2. Koordinat Stasiun Penelitian

\begin{tabular}{|c|c|c|c|c|}
\hline $\begin{array}{l}\text { Stasiun } \\
\text { Penelitian }\end{array}$ & $\begin{array}{l}\text { Titik Koordinat } \\
\text { awal }\end{array}$ & $\begin{array}{c}\text { Titik Koordinat } \\
\text { Akhir }\end{array}$ & $\begin{array}{l}\text { Panjang Linta- } \\
\text { san (m) }\end{array}$ & $\begin{array}{l}\text { Luas Area } \\
\qquad\left(\mathrm{m}^{2}\right)\end{array}$ \\
\hline Lokasi A & $\begin{array}{l}7^{\circ} 39^{\prime} 58^{\prime \prime} \mathrm{S} \\
110^{\circ} 16^{\prime} 2^{\prime \prime} \mathrm{T}\end{array}$ & $\begin{array}{l}7^{\circ} 40^{\prime} 26^{\prime \prime} \mathrm{S} \\
110^{\circ} 16^{\prime} 1^{\prime \prime} \mathrm{T}\end{array}$ & 878,75 & 17197,60874 \\
\hline Lokasi B & $\begin{array}{c}7^{\circ} 42^{\prime} 9^{\prime \prime} \mathrm{S} \\
110^{\circ} 16^{\prime} 60^{\prime \prime} \mathrm{T}\end{array}$ & $\begin{array}{l}7^{\circ} 42^{\prime} 43^{\prime \prime} \mathrm{S} \\
110^{\circ} 17^{\prime} 10^{\prime \prime} \mathrm{T}\end{array}$ & 1214,48 & 16069,709005 \\
\hline Lokasi C & $\begin{array}{l}\text { 7044'47" S } \\
110^{\circ} 19^{\prime} 58^{\prime \prime} \mathrm{T}\end{array}$ & $\begin{array}{l}7^{\circ} 45^{\prime} 15^{\prime \prime} \mathrm{S} \\
110^{\circ} 21^{\prime} 2^{\prime \prime} \mathrm{T}\end{array}$ & 1643 & 14855,841615 \\
\hline Lokasi D & \multicolumn{2}{|c|}{$\begin{array}{c}\text { 7³6'26.76" } \mathrm{S} \\
110^{\circ} 13^{\prime} 28.00^{\prime \prime} \mathrm{T}\end{array}$} & - & - \\
\hline
\end{tabular}

\section{Kondisi Fisik Selokan Mataram}

Selokan Mataram mulai dibangun sekitar tahun 1942 pada masa pemerintahan Sultan Hamengkubuwono IX, untuk menghubungkan Kali Progo di bagian barat dengan Kali Opak di bagian timur. Hal tersebut awalnya bertujuan untuk menyelamatkan rakyat Mataram (kini Yogyakarta) dari kewajiban menjadi romusha di masa pendudukan Jepang. Setelah penggalian selesai, pengelolaan selokan ditangani tenaga pengairan Kasultanan dan diawasi langsung oleh Sri Sultan. Namun, sejak diambil alih pemerintah, Selokan Mataram dikelola oleh Sub-Dinas Pengairan Departemen Pekerjaan Umum. Pengelolaan yang dilakukan termasuk pula perbaikan besar-besaran pada tahun 1969-1975 atas bantuan dana dari Inggris. Perbaikan tersebut meliputi pengerasan selokan sepanjang 32 kilometer, kedalaman dua meter dan lebar 3--5 meter, lengkap dengan pengerasan ruas jalan di sampingnya (http://bulaksumur.tripod.com/september/edisi13/selokan.htm).

Jalan Inspeksi Selokan Mataram terletak pada lereng bawah Gunung Api Merapi, sehingga material penyusunnya didominasi oleh hasil endapan vulkanik yang ada di daerah penelitian termasuk dalam endapan Gunung Api Merapi Muda dengan masa pembentukan zaman Kuarter. Material yang menyusun daerah ini berdasarkan peta Geologi lembar Yogyakarta 1408-02 dan 1407-5 terdiri atas tuff, abu, breksi, aglomerat, dan leleran lava tak terpisahkan. Secara regional, Gunung Api Merapi termasuk dalam zona Solo, terdiri atas 
Jurnal Pendidikan Geografi:

Kajian, Teori, dan Praktik dalam Bidang Pendidikan dan Ilmu Geografi

Tahun 24, Nomor 2, Jun 2019, Hal 108-118

deretan Gunung Api Ungaran-Merapi dan merupakan deretan dari Gunung Api kuarter yang mana Gunung Api Merapi ini terletak pada titik silang dua buah patahan yaitu patahan transversal (arah utara-selatan) dan patahan longitudinal melalui Pulau Jawa. Material yang banyak terbawa dari daerah hulu adalah lempung koloid terutama berasal dari Formasi Sentolo di sebelah timur Sungai Krasak. Material pasir, gravel, dan fragmen lain banyak dijumpai pada formasi Yogyakarta di sebagian besar saluran. Selain material tanah yang terbawa dan diendapkan di dasar selokan, beberapa sampah baik organik maupun anorganik juga banyak dijumpai di sepanjang dasar Selokan Mataram (Adiarti, 2011).

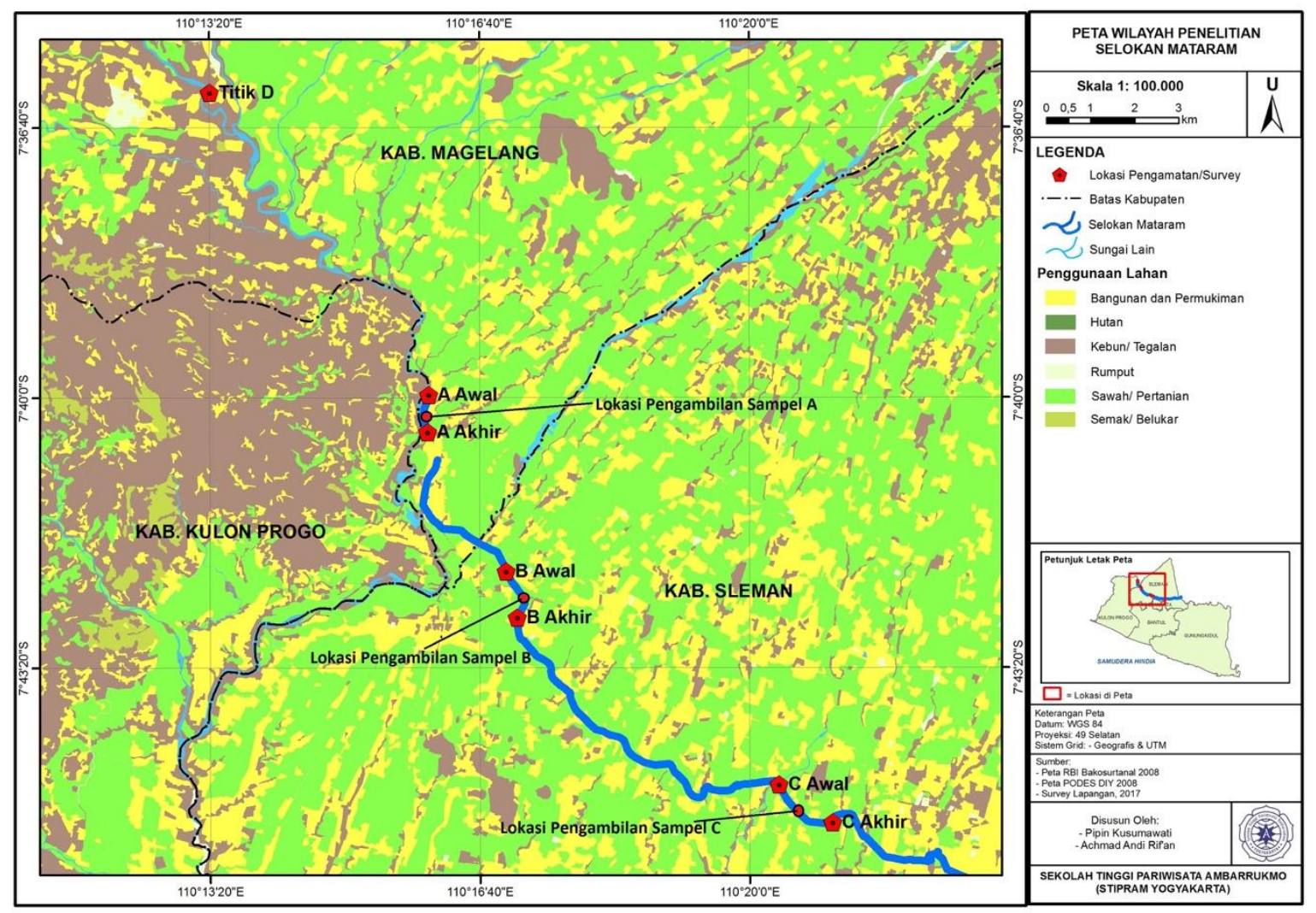

Gambar 1. Pemetaan stasiun penelitian dan titik pengambilan sampel airnya

Konstruksi Selokan Mataram mengalami serangkaian perbaikan sekitar tahun 1980. Perbaikan dilakukan pada dinding dan dasar selokan, terutama yang melewati daerah perkotaan. Beberapa dasar dan dinding penggal saluran Selokan Mataram dilakukan pelantaian. Proses pelantaian dilakukan dengan meletakkan rangkaian batu yang disisipi adukan semen kasar. Selanjutnya pada setiap kurang lebih jarak 200 meter dasar selokan diberi lubang yang berfungsi sebagai resapan air tanah (Jannah, 2014).

Menurut Data di Balai Besar Wilayah Sungai Serayu Opak, Selokan Mataram mempunyai debit 73,59\% dari saluran air yang dialirkan dari Bendungan Karangtalun yang hilirnya merupakan sungai Opak di Klaten, sedangkan sisanya 26,41\% dialirkan ke Saluran Van Der Wijck menuju ke arah Bantul, Yogyakarta.

Saluran pengairan Selokan Mataram yang membentang menyatukan sungai Progo dan sungai Opak ini indah, membentang diantara persawahan warga. di kanan kirinya juga banyak ditumbuhi pohon dan ilalang yang memberi kesan sangat natural dengan aliran airnya yang tenang sangat menyenangkan jika bisa menyusuri Selokan Mataram menggunakan perahu kayak ataupun ban tubing. 
Jurnal Pendidikan Geografi:

Kajian, Teori, dan Praktik dalam Bidang Pendidikan dan Ilmu Geografi

Tahun 24, Nomor 2, Jun 2019, Hal 108-118

Keadaan Selokan Mataram hingga saat ini, lebih dari 30 tahun sejak terakhir waktu perbaikannya menunjukkan di beberapa tempat sudah membutuhkan berbagai perbaikan. Kegiatan perawatan pada pengelolaan Selokan Mataram sangat terbatas. Terbukti pada saat selokan dikosongkan banyak ditemui selokan yang bocor di beberapa titik (Gambar 2). Banyak jembatan yang sudah tidak layak (Gambar 3) dan terlalu rendah/dekat dengan badan air yang mengakibatkan dua hal, yaitu jembatan rawan tererosi apabila air Selokan Mataram meluap sewaktu-waktu dan jembatan yang terlalu rendah membuat selokan tidak bisa dilalui oleh perahu, misalkan untuk kepentingan wisata tirta. Semak belukar tumbuh sangat lebat di berbagai lokasi menunjukkan kurangnya perhatian dari pihak berwenang yang bertanggung jawab terhadap perawatan Selokan Mataram (Gambar 4). Jalanan Inspeksi Selokan Mataram yang membentang di tepi Selokan Mataram yang telah mengalami pelebaran dan mengaspalan juga menunjukkan tanda-tanda kerusakan di beberapa titik.

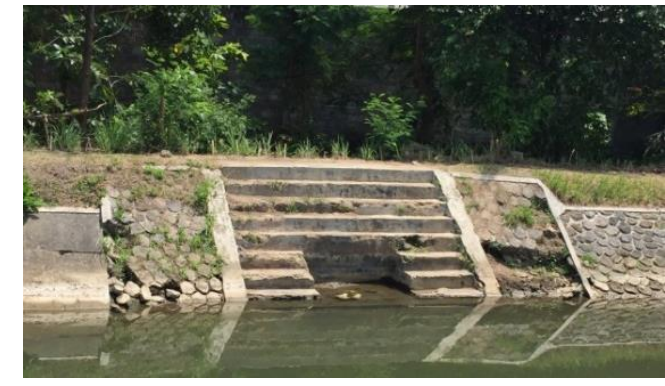

Gambar 2. Kerusakan pada dinding selokan Mataram

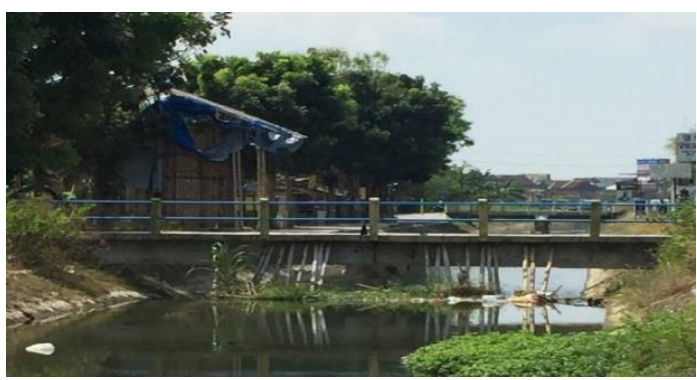

Gambar 3. Jembatan yang mulai retak dan perlu penyangga

Kondisi tersebut diperparah dengan beberapa oknum yang kurang menjaga kebersihan lingkungan Selokan Mataram dengan membuang sampah atau membakar sampah di sepanjang tepi Selokan Mataram atau melemparkan sampah ke badan airnya sehingga menurunkan nilai estetikanya (Gambar 5).

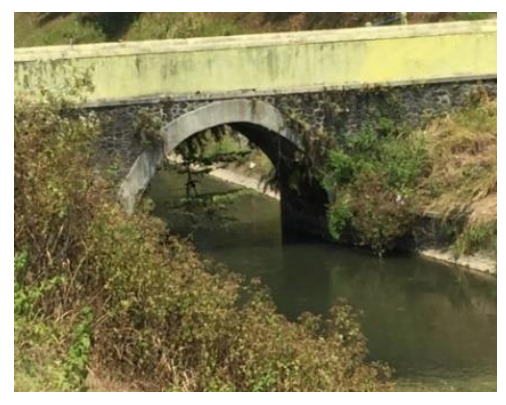

Gambar 4. Semak belukar tumbuh lebat

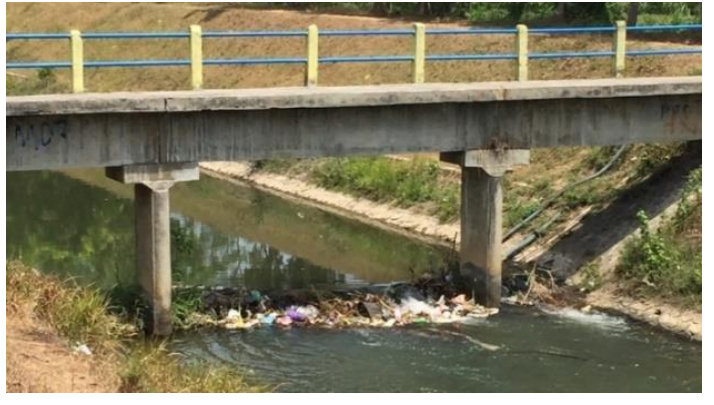

Gambar 5. Banyaknya sampah mengurangi estetika

Walaupun banyak jembatan memiliki jarak terlalu dekat dengan permukaan air Selokan Mataram (Gambar 6), ada juga beberapa jembatan yang desainnya mendukung wisata tirta, seperti terlihat pada Gambar 7.

Ada 4 komponen utama yang wajib dimiliki oleh suatu destinasi wisata yaitu Attraction (daya tarik), Amenities (sarana dan prasarana), Accesibility (akses menuju lokasi) dan Ancillary Service (pelayanan tambahan dari pemerintah daerah) (Utari \& Kampana, 2014). Berdasarkan kelengkapan diatas maka Selokan Mataram hanya memiliki 2 dari komponen utama yaitu Attraction dan Accesibility. Dengan demikian dibutuhkan peran serta pemerintah dan penduduk sekitar untuk menjadikan Selokan Mataram sebagai suatu destinasi wisata. 


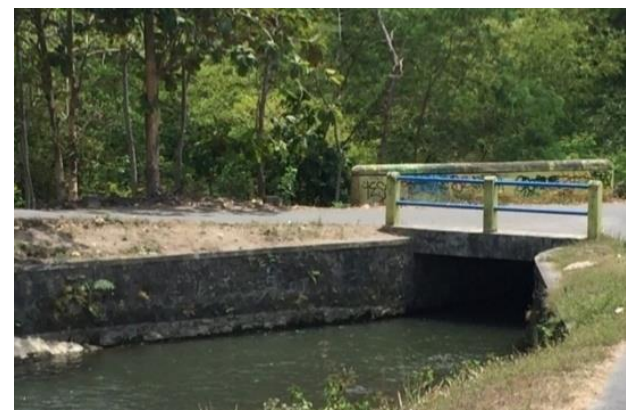

Gambar 6. Jarak permukaan air dan jembatan terlalu dekat

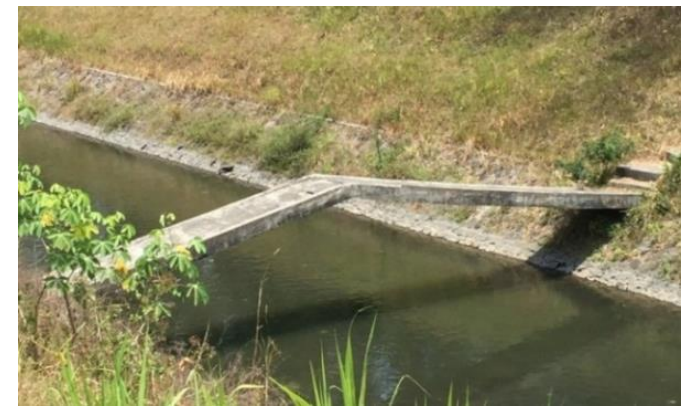

Gambar 7. Desain jembatan dapat mendukung wisata tirta

\section{Kualitas Air Selokan Mataram}

Penelitian ini mengambil empat titik sampel air, yaitu di inlet Selokan Mataram di Desa Bligo sebagai stasiun A, Tirtoadi Sleman sebagai stasiun B Mlati Sleman sebagai stasiun C dan Candi Sungai Progo dekat Candi Mendut sebagai stasiun D. Sampel pada stasiun D dijadikan sebagai referensi kualitas air dari suatu daya tarik wisata tirta yang sudah beroperasi jauh sebelum rencana Selokan Mataram sebagai daya tarik wisata tirta. Stasiun D merupakan hulu dari aliran sungai Progo yang nantinya akan masuk ke dalam aliran Selokan Mataram.

Hal tersebut berdasar pada pertimbangan penelitian yang pernah dilakukan oleh Jannah (2014), hasil penilaian kualitas air di Selokan Mataram pada parameter BOD, COD, $\mathrm{NO}_{2}$ dan nilai $\mathrm{NO}_{3}$ tercatat lebih tinggi pada lokasi pengambilan di Pogung Dalangan dan Santren, menunjukkan di lokasi yang padat penduduk tersebut mendapat lebih banyak air limbah masuk ke dalam badan air Selokan Mataram.

Berdasarkan Peraturan Pemerintah Republik Indonesia (2001) Nomor 82 tentang Pengelolaan Kualitas Air dan Pengendalian Pencemaran Air, air dikelompokkan menjadi 4 kategori, yaitu:

a. Kelas I, air yang peruntukannya dapat digunakan untuk air baku air minum, dan atau peruntukan lain yang mempersyaratkan mutu air yang sama dengan kegunaan tersebut;

b. Kelas II, air yang peruntukannya dapat digunakan untuk prasarana/sarana rekreasi air, pembudidayaan ikan air tawar, peternakan, air untuk mengairi pertanaman, dan atau peruntukan lain yang mempersyaratkan mutu air yang sama dengan kegunaan tersebut;

c. Kelas III, air yang peruntukannya dapat digunakan untuk pembudidayaan ikan air tawar, peternakan, air untuk mengairi pertanaman, dan atau peruntukan lain yang mempersyaratkan mutu air yang sama dengan kegunaan tersebut;

d. Kelas IV, air yang peruntukannya dapat digunakan untuk mengairi pertanaman dan atau peruntukan lain yang mempersyaratkan mutu air yang sama dengan kegunaan tersebut

Air yang aman digunakan adalah air yang sesuai dengan kriteria bagi peruntukan air tersebut. Berdasarkan peraturan PP no.82 tahun 2001 diatas maka Selokan Mataram yang sejak awal diperuntukkan untuk pengairan irigasi cukup menggunakan baku mutu air kelas empat saja.

Pengujian kimiawi dilakukan mengacu pada Peraturan Gubernur Daerah Istimewa Yogyakarta (2008) no.20 tentang Baku Mutu Air. Hasil uji kimiawi sampel air di empat lokasi sampling Selokan Mataram ditampilkan pada Tabel 2. 
Jurnal Pendidikan Geografi:

Kajian, Teori, dan Praktik dalam Bidang Pendidikan dan Ilmu Geografi

Tahun 24, Nomor 2, Jun 2019, Hal 108-118

Tabel 2. Hasil Uji Kimia Sampel Air Selokan Mataram

\begin{tabular}{|c|c|c|c|c|c|c|c|}
\hline \multirow[t]{2}{*}{ No. } & \multirow{2}{*}{ Parameter } & \multirow{2}{*}{ Satuan } & \multicolumn{4}{|c|}{ Hasil Uji per Lokasi Sampling } & \multirow[t]{2}{*}{$\begin{array}{c}\text { Standar Kelas } \\
\text { III }\end{array}$} \\
\hline & & & $\mathrm{A}$ & $\mathrm{B}$ & $\mathrm{C}$ & $\mathrm{D}$ & \\
\hline 1. & Temperatur & ${ }^{\circ} \mathrm{C}$ & - & - & - & - & - \\
\hline 2. & Residu Terlarut (TDS) & $\mathrm{mg} / \mathrm{L}$ & 104 & 104 & 89 & 96 & maks. 1000 \\
\hline 3. & Residu Tersuspensi (TSS) & $\mathrm{mg} / \mathrm{L}$ & 75 & 83 & 97 & 167 & maks.400 \\
\hline 4. & $\mathrm{pH}$ & - & 7,7 & 7,8 & 7,7 & 7,8 & 6-9 \\
\hline 5. & BOD & $\mathrm{mg} / \mathrm{L}$ & 1,5 & 1,9 & 2,7 & 3,1 & maks.6 \\
\hline 6. & COD & $\mathrm{mg} / \mathrm{L}$ & 15,8 & 17,6 & 26,2 & 31,7 & maks.50 \\
\hline 7. & DO & $\mathrm{mg} / \mathrm{L}$ & 6,2 & 7,1 & 6,2 & 7,4 & $\min .4$ \\
\hline 8. & Total Fosfat sebagai P & $\mathrm{mg} / \mathrm{L}$ & 0,436 & 0,338 & 0,299 & 0,480 & maks.1 \\
\hline 9. & Nitrat & $\mathrm{mg} / \mathrm{L}$ & 1,11 & 1,08 & 0,91 & 1,11 & maks.20 \\
\hline 10. & Arsen & $\mathrm{mg} / \mathrm{L}$ & $<0,005$ & $<0,005$ & $<0,005$ & $<0,005$ & maks.1 \\
\hline 11. & Cobalt (Co) & $\mathrm{mg} / \mathrm{L}$ & $<0,0093$ & $<0,0093$ & $<0,0093$ & $<0,0093$ & maks. 0,2 \\
\hline 12. & Boron & $\mathrm{mg} / \mathrm{L}$ & $<0,0120$ & $<0,0120$ & $<0,0120$ & $<0,0120$ & maks.1 \\
\hline 13. & Cadmium (Cd) & $\mathrm{mg} / \mathrm{L}$ & $<0,034$ & $<0,034$ & $<0,034$ & $<0,034$ & maks.0,01 \\
\hline 14. & Kromium (Cr) & $\mathrm{mg} / \mathrm{L}$ & $<0,0014$ & $<0,0014$ & $<0,0014$ & $<0,0014$ & maks. 0,05 \\
\hline 15. & Tembaga $(\mathrm{Cu})$ & $\mathrm{mg} / \mathrm{L}$ & $<0,0069$ & $<0,0069$ & $<0,0069$ & $<0,0069$ & maks. 0,02 \\
\hline 16. & Timbal $(\mathrm{Pb})$ & $\mathrm{mg} / \mathrm{L}$ & $<0,0161$ & $<0,0161$ & $<0,0161$ & $<0,0161$ & maks.0,03 \\
\hline 17. & Seng $(Z n)$ & $\mathrm{mg} / \mathrm{L}$ & $<0,0083$ & $<0,0083$ & $<0,0083$ & $<0,0083$ & maks.0,05 \\
\hline 18. & Klorida & $\mathrm{mg} / \mathrm{L}$ & 6,0 & 7,9 & 6,9 & 6,9 & Maks.600 \\
\hline 19. & Sianida & $\mathrm{mg} / \mathrm{L}$ & Tak & Tak & Tak & Tak & maks.0,02 \\
\hline & & & Terdeteksi & Terdeteksi & Terdeteksi & Terdeteksi & \\
\hline 20. & Flourida $(\mathrm{F})$ & $\mathrm{mg} / \mathrm{L}$ & $<0,0308$ & $<0,0308$ & $<0,0308$ & $<0,0308$ & maks. 1,5 \\
\hline 21. & Nitrit $\left(\mathrm{NO}_{3}\right)$ & $\mathrm{mg} / \mathrm{L}$ & 0,0067 & 0,0058 & 0,0036 & 0,0092 & maks.0,06 \\
\hline 22. & Klor bebas & $\mathrm{mg} / \mathrm{L}$ & $\mathbf{0 , 1}$ & 0,1 & 0,1 & 0,1 & maks.0,03 \\
\hline 23. & Belerang sebagai $\mathrm{H}_{2} \mathrm{~S}$ & $\mathrm{mg} / \mathrm{L}$ & $<0,0046$ & $<0,0046$ & $<0,0046$ & $<0,0046$ & maks.0,02 \\
\hline 24. & Detergen sebagai MBAS & $\mu \mathrm{g} / \mathrm{L}$ & 63,70 & 31,50 & 62,00 & 18,5 & maks.200 \\
\hline 25. & Senyawa Fenol & $\mathrm{mg} / \mathrm{L}$ & $<0,0215$ & $<0,0215$ & $<0,0215$ & $<0,0215$ & maks.1 \\
\hline
\end{tabular}

Berdasarkan hasil uji kimiawi sampel air menunjukkan bahwa air Selokan Mataram dan Sungai Progo berada pada batas aman, pH, kadar DO, BOD, COD, total fosfat dan nitrat berada pada level normal dan keberadaan logam-logam berat tidak menunjukkan jumlah yang signifikan sehingga cukup aman digunakan sebagai wahana wisata tirta kategori kontak menengah. Pengukuran yang menunjukkan melebihi batasan adalah kadar klor bebas. Hasan (2006) menjelaskan bahwa klorin banyak dimanfaatkan manusia sebagai desinfektan dalam bidang kesehatan, pemutih, pestisida (DDT), dan industri lainnya. Pembuangan limbah klorin dalam badan air dapat meracuni ekosistem. Dalam bentuk gas klorin juga merusak ozon dan berkontribusi dalam pembentukan hujan asam.

Faktor utama yang membedakan kategori wisata tirta menengah dengan wisata tirta kontak penuh adalah tingkat kontak terhadap air hanya akan terjadi sesekali (South Africa's Department of Water Affairs and Forestry, 1996). Usia wisatawan yang mengunjungi wisata tirta kategori kontak menengah biasanya remaja hingga dewasa dan dengan status kesehatan yang cukup baik. Hasil uji mikrobiologi menggunakan indikator bakteri coliform. Kadar Coliform sampel air di empat lokasi sampling air dapat dilihat pada Tabel 3.

Berdasarkan hasil uji mikrobiologis menunjukkan bahwa seluruh sampel air di setiap lokasi sampling menunjukkan jumlah coliform, baik fecal coliform maupun total coliform yang melebihi ambang batas yakni sejumlah 2000/mL untuk fecal coliform dan 10.000/mL untuk total coliform menunjukkan air sungai Selokan Mataram banyak tercemar dengan saluran septic tank masyarakat. Hal ini sejalan dengan hasil penelitian Aria et al. (2013) pengaruh limbah seperti feses, sisa makanan maupun kebiasaan penduduk setempat membuang sampah ke sungai merupakan faktor utama penyebab pencemaran lingkungan air. Salah satu alasan pencemaran sungai adalah pertumbuhan penduduk di kota Yogyakarta tidak 
Jurnal Pendidikan Geografi:

Kajian, Teori, dan Praktik dalam Bidang Pendidikan dan Ilmu Geografi

Tahun 24, Nomor 2, Jun 2019, Hal 108-118

diiring dengan pertambahan dan penyediaan lahan memukiman warga yang mendesak warga untuk tinggal di sempadan sungai (Yogafanny, 2015).

Tabel 3 Hasil Uji Coliform Sampel Air

\begin{tabular}{ccccc}
\hline Lokasi Sampling & $\begin{array}{c}\text { Fecal Coliform } \\
\text { (Jumlah/100mL) }\end{array}$ & $\begin{array}{c}\text { Kadar Maksi- } \\
\text { mum*) }\end{array}$ & $\begin{array}{c}\text { Total Coliform } \\
\text { (Jumlah/100mL) }\end{array}$ & $\begin{array}{c}\text { Kadar Maksi- } \\
\text { mum*) }\end{array}$ \\
\hline A & $\mathbf{1 6 . 0 0 0}$ & 2000 & $\mathbf{1 6 . 0 0 0}$ & 10000 \\
B & 1300 & 2000 & 1700 & 10000 \\
C & $\mathbf{5 4 0 0}$ & 2000 & $\mathbf{1 6 . 0 0 0}$ & 10000 \\
D & $\mathbf{3 3 0 0}$ & 2000 & $\mathbf{2 4 . 0 0 0}$ & 10000 \\
\hline
\end{tabular}

Rendahnya kualitas air yang didapatkan pada penelitian ini kemungkinan dipicu oleh keadaan musim penghujan ketika penelitian ini berlangsung. Mengacu pada penelitian Laapo et al. (2009), air laut di kawasan wisata Gugus Pulau Togean Sulawesi Tengah juga mengalami peningkatan nilai kekeruhan, penurunan salinitas dan suhu pada bulan November terkait dengan musim penghujan dan gelombang yang tinggi. Dengan demikian perlu kiranya dilakukan penelitian kualitas air Selokan Mataram pada musim kemarau untuk mengetahui kualitas air Selokan Mataram yang sebenarnya.

Dengan demikian perlu adanya perbaikan Selokan Mataram di berbagai lokasi, pembenahan tata ruang yang baik serta kesadaran dan peran serta positif dari masyarakat setempat untuk mewujudkannya suatu destinasi wisata tirta.

\section{KESIMPULAN}

Selokan Mataram memiliki potensi menjadi destinasi wisata karena dua hal, yakni memiliki nilai historis dengan penduduk Yogyakarta dan juga memiliki bentang alam yang cukup menarik. Akan tetapi hal ini belum diwujudkan hingga saat ini. Hasil penelitian menunjukkan bahwa pemeliharaan Selokan Mataram minim dilakukan oleh pemerintah setempat sehingga dibeberapa titik Selokan Mataram memperlihatkan beberapa kerusakan, jembatan yang sudah mulai retak dan rawan rubuh, ditambah lagi kurangnya kesadaran dari masyarakat Yogyakarta yang sering membuang sampah ke dalam badan air. Kualitas air juga menunjukkan bahwa air Selokan Mataram mengalami pencemaran, baik fisik dan mikrobiologi yang berasal dari limbah manusia. Keadaan kualitas air yang rendah ini kemungkinan dipicu oleh keadaan musim penghujan ketika penelitian ini berlangsung sehingga menimbulkan bias terhadap hasil uji kualitas airnya. Dengan demikian perlu kiranya dilakukan penelitian kualitas air Selokan Mataram pada musim kemarau untuk mengetahui kualitas air Selokan Mataram yang sebenarnya sehingga dapat dinilai kelayakannya untuk dibukanya suatu destinasi wisata tirta.

\section{DAFTAR RUJUKAN}

Adiarti, I. (2011). Kajian karakteristik muka air tanah di sekitar Selokan Mataram. Yogyakarta: Fakultas Geografi. Universitas Gadjah Mada.

Asrini, K., Adnyana, I. W., Rai, \& Nyoman, I. (2017). Studi analisis kualitas air di Daerah Aliran Sungai Pakerisan Provinsi Bali. ECOTROPHIC : Jurnal Ilmu Lingkungan (Journal of Environmental Science), 101-107.

DIY, G. (2008). Peraturan Gubernur DI Yogyakarta No.20 Tahun 2008 tentang Baku Mutu Air. DIY: jogjaprov.go.id.

Forestry, D. o. (1996). South African Water Quality Guidelines Volume 2 Recreational Use. South Africa: Department of Water Affairs and Forestry. 
Jurnal Pendidikan Geografi:

Kajian, Teori, dan Praktik dalam Bidang Pendidikan dan Ilmu Geografi

Tahun 24, Nomor 2, Jun 2019, Hal 108-118

Gutt, C., \& T, V. (2002). Tourism planning 4th edition: basics, concepts \& cases. New York: Routledge.

Hadi, U. (2017, September 13). detik.com. Retrieved from detikNews: https://news.detik.com/berita-jawa-tengah/d-3641905/selokan-mataram-di-yogyasarat-nilai-sejarah-justru-dipenuhi-sampah

Hadiyanti, A., \& Wibisono, B. H. (2012). Pola penggunaan ruang di Kawasan Sempadan Selokan Mataram Yogyakarta. Tata Loka, 295-303.

Hasan, A. (2006). Dampak penggunaan Klorin. Jurnal Teknologi Lingkungan, 90-96.

Indonesia, M. K. (2017). Peraturan Menteri Kesehatan no. 32 tahun 2017 tentang standar baku mutu kesehatan lingkungan dan persyaratan kesehatan air untuk keperluan higiene sanitasi, kolam re-nang, solus per aqua, dan pemandian umum. Indonesia: Kemkes.

Indonesia, P. R. (2009). Undang-Undang Republik Indonesia nomor 10 tahun 2009 tentang kepariwisataan. Indonesia: -.

Jannah, M. (2014). Pengaruh Kanal Yoshiro (Selokan Mataram) terhadap kualitas air tanah di daerah antara Kali Code dan Kali Pelang. Yogyakarta: Fakultas Geografi UGM.

Karyono, A. (1997). Kepariwisataan. Jakarta: Gramedia Widiasarana.

Laapo, A., Fahrudin, A., Bengen, D. G., \& Damar, A. (2009). Pengaruh aktivitas wisata bahari terhadap kualitas perairan laut di kawasan wisata gugus Pulau Togean. Ilmu Kelautan, 215-221.

M, W. R. (2018). Water based tourism and recreation challenges in West Java Province. 1st UPI International Geography Seminar 2017 (pp. 1-7). Bandung: IOP Conference Series: Earth and Environmental Science.

Rahmafitria, F., Wirakusuma, R. M., \& Riswandi, A. (2017). Development of tourism potential in watersports recreation, Santirah River, Pangandaran Regency, Indonesia. PEOPLE: International Journal of Social Sciences, 712-720.

Rif'an, A. A. (2016). Tourism components and tourists characteristic of prambanan temple as the world cultural heritage site in Yogyakarta, Indonesia. International Journal of Tourism and Hospitality Study, 11-21.

Romaito, R., Patana, P., \& Harahap, Z. A. (2014). Kajian kesesuaian wisata dan daya dukung kawasan wisata Sungai Bingai Namu Sira-Sira Langkat Sumatera Utara. Jurnal AQUACOASTMARINE, 52-59.

Soekadijo, R. G. (2000). Anatomi pariwisata (memahami pariwisata sebagai systemic linkage). Jakarta: PT. Gramedia Pustaka Umum.

Suyasa W, B., Pancadewi G.A, S. K., Suprihatin, I. E., \& Suastuti G.A, D. A. (2018). Kualitas air sungai di kawasan wisata Pantai Petitengget, Kerobokan Kabupaten Badung Bali. ECOTROPHIC, 225-238.

Utama, I. G., \& Mahadewi, N. M. (2012). Metodologi penelitian pariwisata dan perhotelan. Yogyakarta: CV Andi Offset.

Utari, P. S., \& Kampana, I. M. (2014). Perencanaan fasilitas pariwisata (tourism amenities) Pantai Pandawa Desa Kutuh Ku-ta Selatan Badung Bali. Jurnal Destinasi Pariwisata, 57-67.

Yogafanny, E. (2015). Pengaruh aktifitas warga di sempadan sungai terhadap kualitas air Sungai Winongo. Jurnal Sains dan Teknologi Lingkungan, 41-50. 